\title{
Improvement and prediction of secondary metabolites production under yeast extract elicitation of Azadirachta indica cell suspension culture using response surface methodology
}

\author{
Reza Farjaminezhad (10 and Ghasemali Garoosi ${ }^{*}$ (])
}

\begin{abstract}
Neem is a medicinal plant used as antimalarial, antibacterial, antiviral, insecticide, and antimicrobial drug. This study aimed to investigate and predict the effect of yeast extract and sampling time on cell growth, secondary metabolites synthesis, SQS1 and MOF1 genes expression by response surface methodology. The highest fresh and dry cell weights were $580.25 \mathrm{~g} / \mathrm{L}$ and $21.01 \mathrm{~g} / \mathrm{L}$, respectively obtained 6 days after using $100 \mathrm{mg} / \mathrm{L}$ yeast extract. The highest azadirachtin accumulation and production were $16.08 \mathrm{mg} / \mathrm{g}$ DW and $219.78 \mathrm{mg} / \mathrm{L}$ obtained 2 and 4 days, respectively after using $25 \mathrm{mg} / \mathrm{L}$ yeast extract. Maximum mevalonic acid accumulation $(1.75 \mathrm{mg} / \mathrm{g} \mathrm{DW})$ and production ( $23.77 \mathrm{mg} / \mathrm{L}$ ) were observed 2 days after application of $50 \mathrm{mg} / \mathrm{L}$ yeast extract. The highest amount of squalene accumulation $(0.22 \mathrm{mg} / \mathrm{g} \mathrm{DW}$ ) and production $(4.53 \mathrm{mg} / \mathrm{L}$ ) were achieved 4 days after using $50 \mathrm{mg} / \mathrm{L}$ yeast extract. Prediction results exhibited the highest azadirachtin accumulation $(13.61 \mathrm{mg} / \mathrm{g} \mathrm{DW})$ and production $(190.50 \mathrm{mg} / \mathrm{L})$, mevalonic acid accumulation $(0.50 \mathrm{mg} / \mathrm{g} \mathrm{DW})$ and production $(5.57 \mathrm{mg} / \mathrm{L})$, and squalene accumulation $(0.30 \mathrm{mg} / \mathrm{g}$ DW) by using $245 \mathrm{mg} / \mathrm{L}$ yeast extract for 2 days, $71 \mathrm{mg} / \mathrm{L}$ yeast extract for 2 days, $200 \mathrm{mg} / \mathrm{L}$ yeast extract for 4.96 days, without yeast extract for 6.54 days and 4 days, respectively. Also, it was predicted that the highest squalene production is achieved by long-term exposure to high concentrations of yeast extract. The GRT-PCR analysis displayed the maximum relative gene expression of SQS1 and MOF1 by using 150 and 25 mg/L yeast extract for 4 and 2 days treatment.
\end{abstract}

Keywords: Azadiractin, Callus induction, Medicinal plant, Mevalonic acid, Neem, Squalene

\section{Introduction}

Plants are a rich source of medicinal compounds which are used to make medicine. About a quarter of the drugs approved by the Food and Drug Administration and European Medicines Agency are produced from plants, which shows their importance (Borkotoky and Banerjee 2020; Thomford et al. 2018). Neem (Azadirachta indica) is a member of the Meliaceae family and very important

\footnotetext{
${ }^{*}$ Correspondence: garoosi@eng.ikiu.ac.ir

Department of Biotechnology, Faculty of Agriculture and Natural Resources, Imam Khomeini International University (IKIU), P. O. Box 288 34149-16818 Qazvin, Islamic Republic of Iran
}

in traditional medicine. Studies have shown that neem leaf extract has free radical scavenging and anti-inflammatory activity and inhibits HSV-1 and MHV viruses (Alzohairy 2016; Sarkar et al. 2020; Tiwari et al. 2010). It has been reported that neem leaf extract can increase immunity against HIV/AIDS by increasing $\mathrm{CD} 4^{+}$cell levels (Mbah et al. 2007). Also, it has been reported that neem extract may be used against the COVID-19 infection (Roy and Bhattacharyya 2020). Neem tree has a variety of secondary metabolites, including azadirachtin, mevalonic acid, squalene, nimbin, nimbiol, polyphenolic flavonoids, etc. (Borkotoky and Banerjee 2020; Farjaminezhad and Garoosi 2020). 
Secondary metabolites are not necessary to maintain the plant life cycle but play an important role in environmental adaptation (Park et al. 2020). Secondary metabolites have various uses and are mainly used as drugs, flavorings, fragrances, pigments, bio-pesticides, and food additives (Murthy et al. 2014). Studies show that the production of secondary metabolites depends on plant genetics, environmental factors, climate, season, growth period, plant parts, pre- and post-harvest processes, and extraction methods (Açıkgöz 2020). All of these factors create problems in the production of secondary metabolites in the traditional method and increases the cost of production (Ramachandra Rao and Ravishankar 2002). Therefore, plant tissue culture is used to produce secondary metabolites due to its reliability and predictability, independence from geographical, seasonal and environmental factors, modification or elimination of unwanted taste, and production of high quality and standard product (Abd El-Salam et al. 2015). Cell suspension culture is the best option to increase the production of secondary metabolites and respond to the increasing industrial demand for secondary metabolites (Rani et al. 2020).

There are several strategies to improve the production of secondary metabolites in plant tissue and cell culture (Park et al. 2020). One of these strategies is the use of elicitors. Elicitors are compounds that stimulate the production of secondary metabolites by biochemical changes in the plant (Namdeo 2007). Elicitors do this by activating the signal transduction cascades (Karalija et al. 2020). These signals act as stress factors and regulate enzyme activity and the production of secondary metabolites (Sharma and Agrawal 2018). Elicitors are divided into two types depending on the origin including biotic and abiotic. Biotic elicitors are produced from microbial or plant sources. Yeast extract is one of the biotic elicitors which derived from microbial sources (Ramirez-Estrada et al. 2016). Yeast extract contains various compounds such as chitin, $\beta$-glucan, glycopeptides, and ergosterol that are involved in plant defense responses (Baenas et al. 2014). It is one of the most common natural elicitors used in in vitro culture to induce secondary metabolites production (Cheng et al. 2013; Karalija et al. 2020). It has been used also successfully in various studies to improve the production of secondary metabolites such as rosmarinic acid (Gonçalves et al. 2019), sanguinarine (Guízar-González et al. 2016), xanthone (KrstićMilošević et al. 2017) isoflavonoid (Rani et al. 2020), plumbagin (Singh et al. 2020) and astragalosides (Park et al. 2020).

An experimental design is a set of tools for studying a system which includes planning and performing a set of experiments to determine the impact of the studied variables on that system. In such experiments, the obtained valid model is a model that contains valuable information about the effect of experimental conditions on the measurement response rate. The required experiment is performed in such a way in which a large amount of information is obtained from a limited number of experiments. Once the appropriate model is obtained, it can be used to predict future observations within the original design range. Therefore, it is necessary to use an appropriate experimental design to develop and optimize a wide range of laboratory studies. The response surface methodology (RSM), which includes statistical and mathematical tools, was first used in chemical experiments for designing and analyzing response surfaces. The experimental design method and the response surface methodology are closely related together and using the RSM methodology is based on experimental data (Mäkelä 2017). This statistical model is an effective tool for optimizing complex processes and save time during the experimental phase (Menezes Maciel Bindes et al. 2019). In the present study the effect of yeast extract and sampling time on cell growth, azadirachtin, mevalonic acid and squalene accumulation and production were investigated and predicted their effects on azadirachtin, mevalonic acid and squalene accumulation and production by response surface methodology. Also, the effect of yeast extract was studied on the squalene synthase 1 (SQS1) and squalene epoxidase 1 (MOF1) genes expression. This is the first comprehensive study on gene expression and prediction on the effect of yeast extract on cell suspension culture of neem and so far no study has been done.

\section{Material and methods}

\section{Plant material and cell suspension culture establishment}

The leaves of neem were collected from Bandar Abbas city of Iran. The leaves were surface sterilized with ethanol and sodium hypochlorite and cultured on MS medium containing $1 \mathrm{mg} / \mathrm{L}$ picloram and $2 \mathrm{mg} / \mathrm{L}$ kinetin. Then cultures were maintained in the growth chamber at $25 \pm 2{ }^{\circ} \mathrm{C}$ in the dark. The friable calli were transferred to the liquid MS medium with the same concentrations of picloram and kinetin and kept on a rotary shaker at $110 \mathrm{rpm}$ and $26 \pm 2{ }^{\circ} \mathrm{C}$ in the dark and sub-cultured every 12 days (Farjaminezhad and Garoosi 2019).

\section{Elicitation with yeast extract}

The cell suspension cultures were transferred to $100 \mathrm{~mL}$ Erlenmeyer flasks containing $25 \mathrm{~mL}$ liquid MS medium supplemented with $1 \mathrm{mg} / \mathrm{L}$ picloram and $2 \mathrm{mg} / \mathrm{L}$ kinetin with an initial cell density of $2.6 \times 10^{5}(\mathrm{SCV}=8 \%)$. The stock solution of yeast extract (Merck, Germany) was prepared by dissolving of yeast extract in distilled water and then filtered using a $0.22 \mu \mathrm{m}$ syringe filter. According to our previous study growth curve (Farjaminezhad 
and Garoosi 2019), eight days after cell culture different concentrations of yeast extract including $0,25,50,100$, 150 and $200 \mathrm{mg} / \mathrm{L}$ were added to cell suspension cultures. The cultures were kept on a rotary shaker at $110 \mathrm{rpm}$ and $26 \pm 2{ }^{\circ} \mathrm{C}$ in the dark and sampling was performed after 2 , $4,6,8,10$ and 12 days of each treatment.

\section{Fresh and dry cell weight measurement}

Fresh and dry cell weights were measured as described by Godoy-Hernández and Vázquez-Flota (2006) with a little modification. For this purpose the cells were collected by Whatman No. 1 filter paper using Büchner funnel under vacuum condition for $30 \mathrm{~s}$ and weighed immediately. Then, the collected cells transferred to the oven at $50{ }^{\circ} \mathrm{C}$ for $72 \mathrm{~h}$ and weighed immediately for dry cell weight.

\section{Mevalonic acid, squalene and azadirachtin extraction}

Azadirachtin, mevalonic acid, and squalene were extracted by using Rafiq and Dahot (2010) method with some modifications. One milliliter of dichloromethane was added to $100 \mathrm{mg}$ of dried and powdered cells and then sonicated for $25 \mathrm{~min}$ at room temperature. The supernatant was collected after centrifugation at $7000 \mathrm{rpm}$ for $15 \mathrm{~min}$. The procedure was repeated for two times. Finally, the dichloromethane was evaporated at $50{ }^{\circ} \mathrm{C}$ in a water and the samples were dried as described above. The dried samples then were re-dissolved in $1.50 \mathrm{~mL}$ HPLC-grade distilled water and stored at $-20{ }^{\circ} \mathrm{C}$.

\section{HPLC analysis}

The HPLC analysis was performed using a Knauer HPLC-DAD system (DAD detector, Azura, Germany) with a Toso C18 column (TSKgel-ODS, $5 \mu \mathrm{m}, 4.60 \times 250 \mathrm{~mm}$, Japan). The mobile phase was acetonitrile:water (10:90) at a flow rate of $0.90 \mathrm{~mL} / \mathrm{min}$. The detection wavelength for azadirachtin (Sigma, USA), mevalonic acid (Sigma, USA), and squalene (Sigma, USA) were set at 214, 270 and $195 \mathrm{~nm}$, respectively. The injection volume of samples was $20 \mu \mathrm{L}$. The azadirachtin, squalene, and mevalonic acid accumulation were estimated from the standard curve of concentration versus the peak area. Also, the amount of azadirachtin, mevalonic acid, and squalene production was calculated by multiplying the amount of azadirachtin, mevalonic acid, and squalene accumulation in their dry cell weight, respectively (Farjaminezhad and Garoosi 2020).

\section{RNA extraction, CDNA synthesis and qRT-PCR analysis}

For RNA extraction, cDNA synthesis, and qRT-PCR analysis, those samples with the highest amount of azadirachtin accumulation at each concentration of yeast extract were used. Total RNA was extracted using an
RNX-Plus kit (Cinaclon, Iran) based on the producer's protocol. The quantity of extracted RNA was measured by a Nano-Drop 200C spectrophotometer (Thermo Scientific, USA). Then, extracted total RNAs were treated with DNase I, RNase-free (Sinaclon, Iran) according to the producer's guidance to eliminate remaining genomic DNA. Single-strand cDNA was synthesized by using a mixture of $5 \mu \mathrm{g}$ of total RNA, $0.50 \mu \mathrm{g} / \mu \mathrm{L}$ Oligo $(\mathrm{dT})_{18}$ primer (Cinaclon, Iran) and $12.50 \mu \mathrm{L}$ DEPC-treated water in the tube. The tube was maintained at $65{ }^{\circ} \mathrm{C}$ for $5 \mathrm{~min}$ and immediately transferred onto ice. Then, $2 \mu \mathrm{L} 10 \times$ reaction buffer (Cinaclon, Iran), $2 \mu \mathrm{L}$ dNTP Mix $10 \mathrm{mM}$ (Cinaclon, Iran) and $1 \mu \mathrm{L}$ M-MuLv reverse transcriptase enzyme $(200 \mu / \mu \mathrm{L}$, Cinaclon, Iran) were added into tube and maintained at $42{ }^{\circ} \mathrm{C}$ for $60 \mathrm{~min}$. The reaction was terminated by heating the mixture at $70{ }^{\circ} \mathrm{C}$ for $10 \mathrm{~min}$. The reverse transcription reaction product was stored at $-20{ }^{\circ} \mathrm{C}$ untile qRT-PCR analysis. The qRT-PCR analysis performed by real-time PCR (Applied Biosystems StepOnePlus, USA) with specific primers for squalene synthase (SQS1) gene (forward: 5'-GCTGAAAATGGCTGTGAG GC-3' and reverse: GTCAGTCCCGAGCTGTTGAA-3'), squalene epoxidase 1 (MOF1) gene (forward: 5'-TCA AATCTGCGCCGTTCTCT-3' and reverse: 5'-AGA ATGACATGCCCGTGGTT-3) and housekeeping 18S ribosomal RNA gene (forward: 5'-CACCACACAACT CTCCCCAT-3' and reverse: 5'ATCAACCACCGTAGT GTCGC-3). The qRT-PCR mixture contained $1 \mu \mathrm{L}$ of synthesized cDNA (50 ng), 7.50 $\mu \mathrm{L}$ SYBR Green Premix Ex Taq II (Takara, Japan), $0.50 \mu \mathrm{L}$ of $10 \mu \mathrm{mol}$ of genespecific primer pairs, and $6 \mu \mathrm{L}$ of nuclease-free water in a final volume of $15 \mu \mathrm{L}$. qRT-PCR conditions consisted of primary denaturation at $95{ }^{\circ} \mathrm{C}$ for $2 \mathrm{~min}$, followed by 35 cycles of denaturation at $95^{\circ} \mathrm{C}$ for $30 \mathrm{~s}$, annealing and extension steps at $57{ }^{\circ} \mathrm{C}$ for $30 \mathrm{~s}$ and at $72{ }^{\circ} \mathrm{C}$ for $30 \mathrm{~s}$, respectively. Finally, the data were analyzed using a $2^{-}$ ${ }^{\Delta \Delta C \mathrm{CT}}$ method (Livak and Schmittgen 2001).

\section{Statistical analysis and experimental design by response surface methodology (RSM)}

The treatment of yeast extract was performed in factorial experiment based on a completely randomized design in triplicate in which the first factor was the different concentrations of yeast extract and the second factor was different sampling times. Data were analyzed by IBM SPSS Statistics software, Version 24.0 (Armonk, NY, USA). The measured indices means compared by using Duncan's multiple range test at a probability level of 0.01 . The qRTPCR analysis of SQS1 and MOF1 genes performed in two biological and two technical replications separately. The mean comparison of relative expression of genes also was carried out using Duncan's multiple range test at a probability level of 0.01 . 
Response surface methodology was used to study the effects of independent variables including different concentrations of yeast extract and different sampling time as well as their interaction on accumulation and production of azadirachtin, mevalonic acid, and squalene. The sampling times were selected based on preliminary studies. The central composite design (CCD) with two variables and five different levels $(-2,-1,0,+1,+2)$ was used for the optimization of yeast extract concentration and sampling time. A total of 13 experiments were conducted to test the five levels of yeast extract and sampling time with full-factorial CCD. By using coded units, the experimental and predicted values for the azadirachtin, mevalonic acid, and squalene accumulation and production in terms of the different variables of yeast extract and sampling time are presented in Tables 1 and 2. The predicted response was calculated using the quadratic polynomial model. The predicted responses which were calculated by a second-order polynomial (quadratic) model is shown as following:

$$
\mathrm{Y}=\beta_{0}+\sum_{\mathrm{i}=1}^{\mathrm{n}} \beta_{\mathrm{i}} \mathrm{X}_{\mathrm{i}}+\sum_{\mathrm{i}=1}^{\mathrm{n}} \beta_{\mathrm{ii}} \mathrm{X}_{\mathrm{i}}^{2}+\sum_{\mathrm{i}=1}^{\mathrm{n}-1} \sum_{\substack{j=2 \\ j>i}} \beta_{\mathrm{ij}} \mathrm{X}_{\mathrm{i}} \mathrm{X}_{\mathrm{j}},
$$

where, $\mathrm{Y}$ is the response variable, $\beta_{0}$ is the average response obtained during replicated experiments of the
CCD; $\beta_{\mathrm{i}}, \beta_{\mathrm{ii}}$, and $\beta_{\mathrm{ij}}$ are the linear, quadratic, and crossproduct effects, respectively; $X_{i}$ and $X_{j}$ are the independent coded variables. Response surface regression coefficient and Analysis of Variance (ANOVA) predicted the effects of independent variables on azadirachtin, mevalonic acid, and squalene accumulation and production from cell suspension culture of neem. The data were analyzed using Design Expert (12.0.0 version) software.

\section{Results}

\section{Fresh and dry cell weight}

Figure 1a-c shows the leaf explant, callus production, and cell suspension culture of $A$. indica. The obtained results demonstrated that different yeast extract concentrations, sampling time, and their interactions affected both the fresh and dry cell weight (Table 3 ). The investigation of the main effect of the application of yeast extract showed that the fresh and dry cell weight decreases; so that, the use of yeast extract alone and regardless of the sampling time had a negative effect on neem cell suspension culture growth. The most suitable condition for neem cell suspension growth was control without any concentrations of yeast extract. Under these conditions, the mass of fresh and dry cell weight were maximized, which were $413.41 \mathrm{~g} / \mathrm{L}$ and $14.47 \mathrm{~g} / \mathrm{L}$, respectively. Based on results, by addition $25,50,100,150$ and $200 \mathrm{mg} / \mathrm{L}$ of yeast extract in comparing to the control, the fresh cell

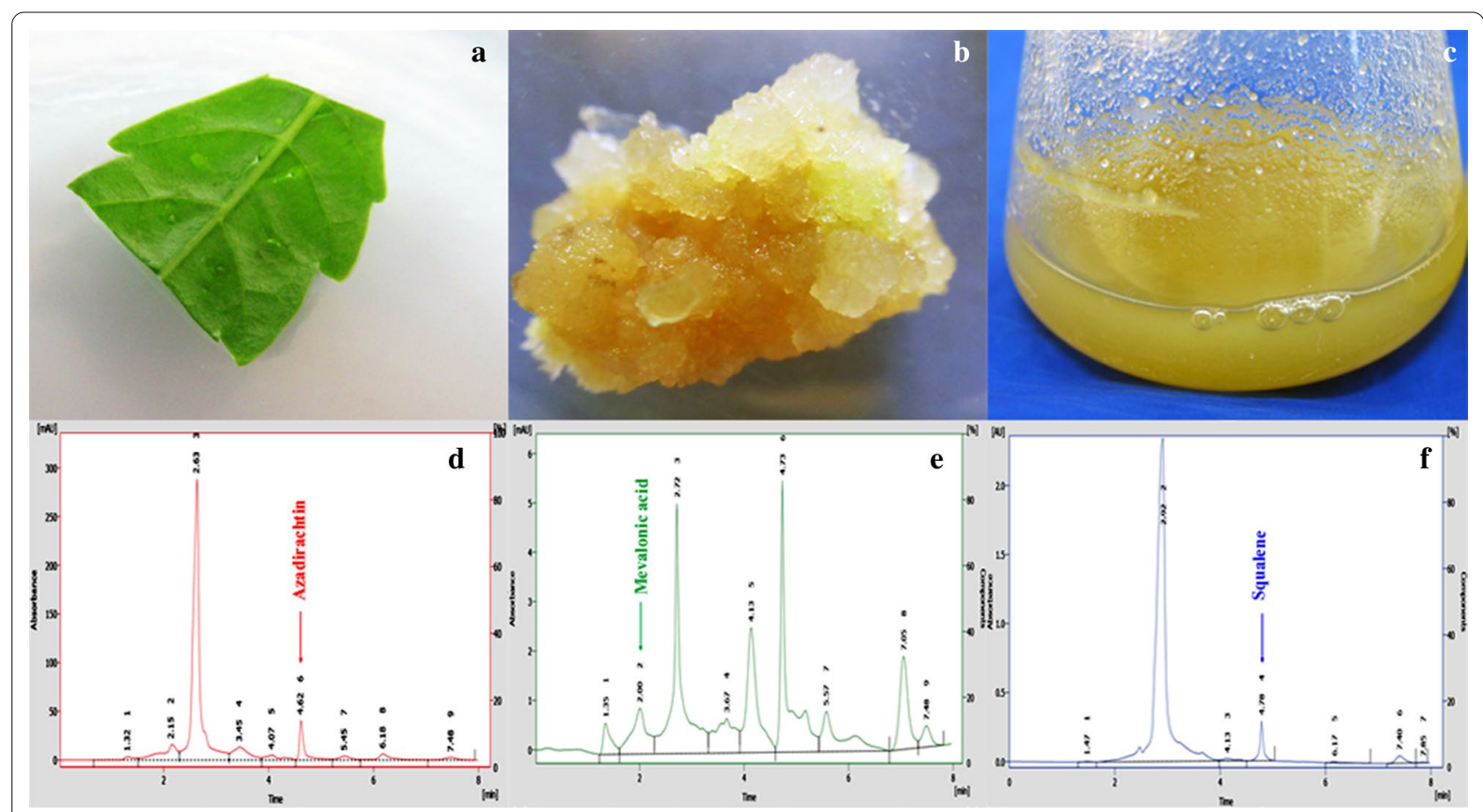

Fig. 1 The leaf explant (a), callus production (b), established cell suspension culture of A. indica (c), and HPLC chromatograms of azadirachtin (d), mevalonic acid (e), and squalene (f) 


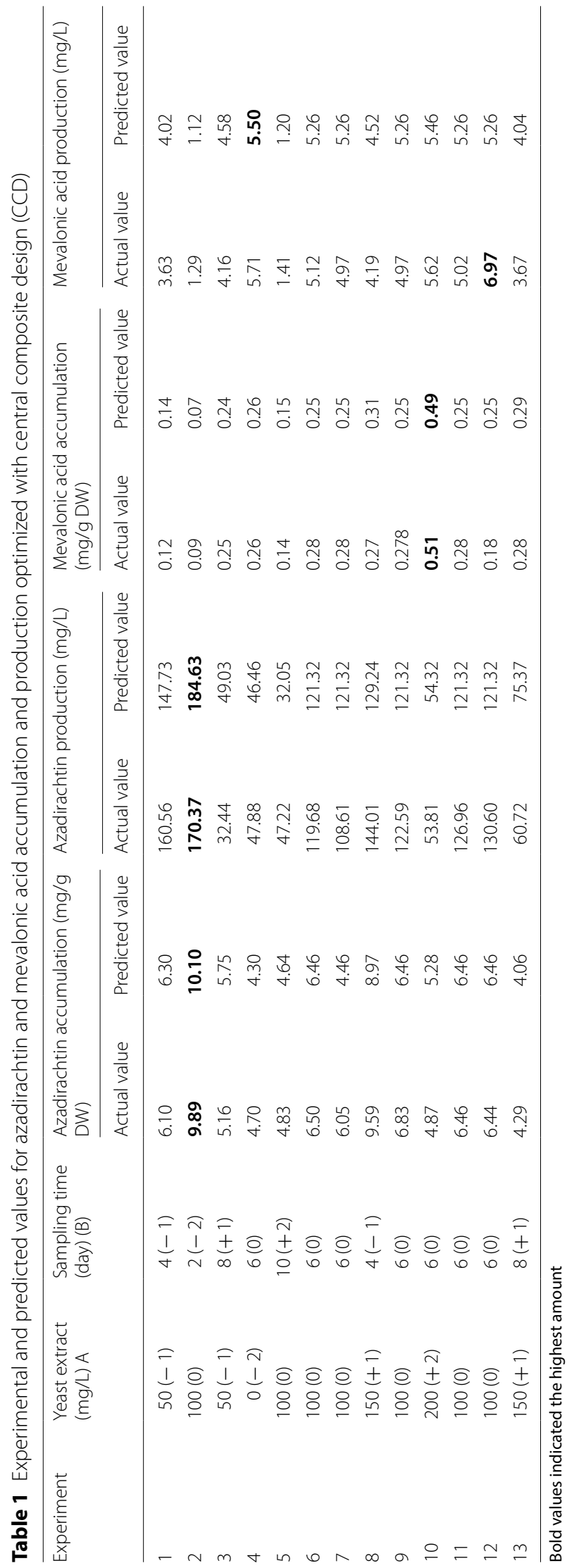

weight reduced 29.61, 35.61, 27.73, 45.52 and $48.66 \%$ and the dry cell weight reduced 22.53, 25.57, 8.64, 27.99 and $33.86 \%$, respectively. The sampling time of 6 and 4 days gave the highest fresh cell weight and dry cell weight of $410.69 \mathrm{~g} / \mathrm{L}$ and $16.23 \mathrm{~g} / \mathrm{L}$. The fresh cell weight increased from the 2nd day to the 6th day of sampling time and decreased from the 6th day to the 12th day; meanwhile, the dry cell weight increased from the 2 nd day to the 4 th day of sampling time and decreased from the 4th day to the 12th day. However, the fresh cell weight on the 6th day of sampling was 47.00, 1.66, 88.52, 111.52 and $104.56 \%$ higher than those on 2 nd, 4th, 8th, 10th and 12th days of sampling and also dry cell weight on 4th day of sampling time was 22.67, 9.90, 80.05, 95.30 and 99.96\% higher than those on 2nd, 6th, 8th, 10th and 12th days of sampling time. By interaction study of the effect of different concentrations of yeast extract and sampling times, it was found the highest fresh and dry cell weight were $580.25 \mathrm{~g} / \mathrm{L}$ and $21.01 \mathrm{~g} / \mathrm{L}$ on 6 th day after addition $100 \mathrm{mg} / \mathrm{L}$ of yeast extract and on 4th day after using $50 \mathrm{mg} / \mathrm{L}$ of yeast extract. In this treatments, fresh cell weight increased 9.00, 50.86, 23.23, 109.97 and 146.06\% compared to control, 25,75 , and $100 \mathrm{mg} / \mathrm{L}$ of yeast extract at same sampling time and the dry cell weight increased 24.17, 34.33, 21.37, 40.91 and 81.43\% compared to the control, 25,75 , and $100 \mathrm{mg} / \mathrm{L}$ of yeast extract at same sampling time (Additional file 1: Table S1).

\section{Azaidrachtin accumulation and production}

The HPLC chromatogram of azadirachtin showed in Fig. 1d. The analysis demonstrated that the applied concentrations of yeast extract, sampling times, and their interaction significantly stimulated the azadirachtin accumulation and production in treated cells compared to the control (Table 3). Accumulation and production of azadirachtin showed a dose-dependent response to the yeast extract. A more increase in azadirachtin accumulation and production was observed at $25 \mathrm{mg} / \mathrm{L}$ yeast extract. Yeast extract at the lower concentration of $25 \mathrm{mg} / \mathrm{L}$ showed the highest azadirachtin accumulation and production which was $9.67 \mathrm{mg} / \mathrm{g}$ DW and $118.53 \mathrm{mg} / \mathrm{L}$. The azadirachtin accumulation and production from control treatment to $25 \mathrm{mg} / \mathrm{L}$ of yeast extract increased and then decreased along with increasing yeast extract concentration from 25 to $100 \mathrm{mg} / \mathrm{L}$. At the $25 \mathrm{mg} / \mathrm{L}$ of yeast extract the azadirachtin accumulation was $161.57,19.79,42.45,36.34$ and $59.37 \%$ and the azadirachtin production was 119.74, 33.80, 31.16, 51.28 and $106.81 \%$ higher than control, 50, 100, 150, and $200 \mathrm{mg} / \mathrm{L}$ (Fig. 2a). In terms of sampling time, the highest azadirachtin accumulation and production were $9.20 \mathrm{mg} / \mathrm{g}$ DW and $125.65 \mathrm{mg} / \mathrm{L}$ observed at 2 days after treatment. On the 2nd day of sampling time, the azadirachtin 

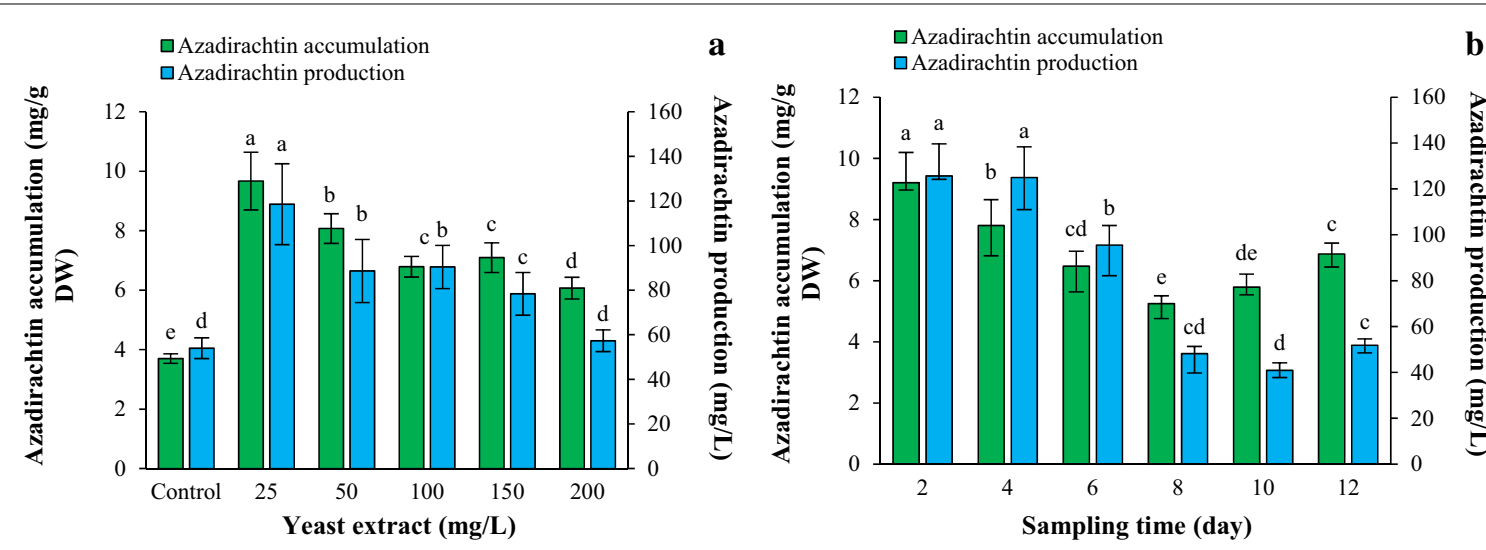

c
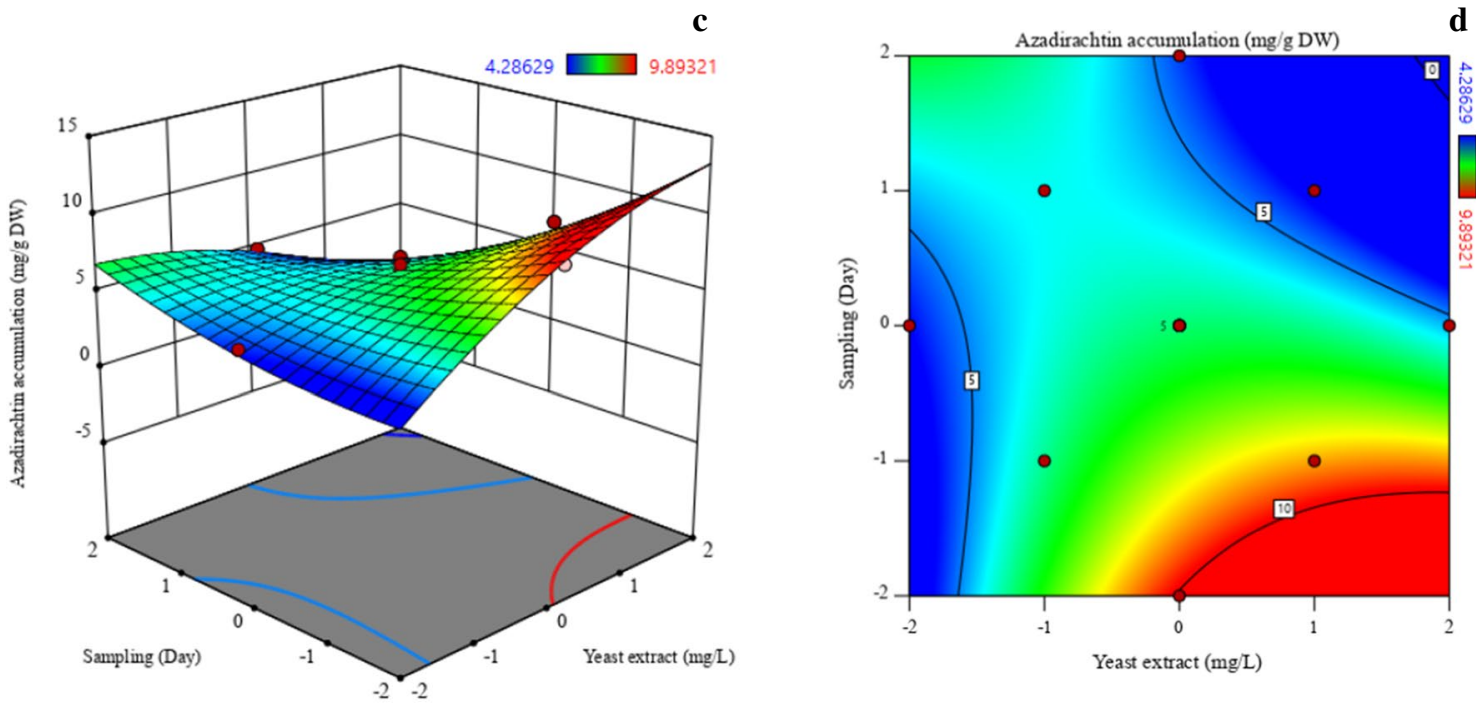

e

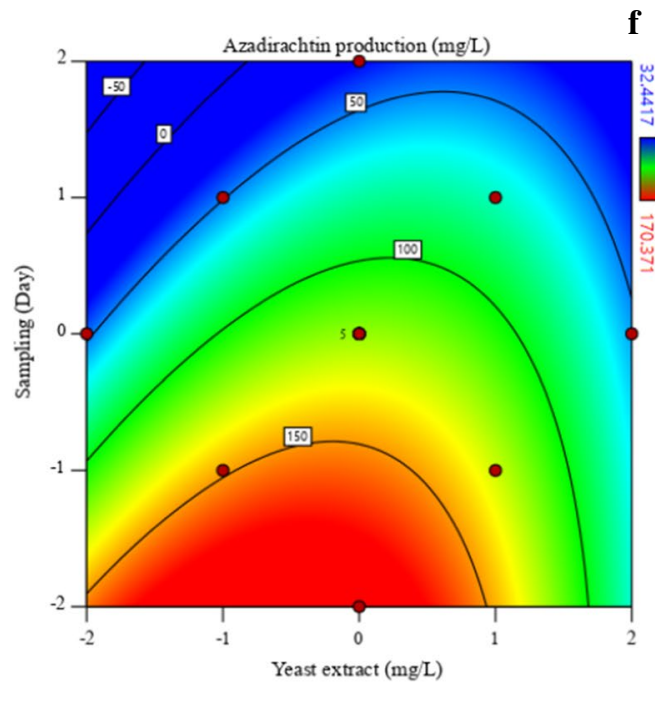

Fig. 2 The effect of different concentrations of yeast extract and sampling times $(\mathbf{a}, \mathbf{b})$ and response surface and contour plots for azadirachtin accumulation (c, $\mathbf{d})$ and azadirachtin production $(\mathbf{e}, \mathbf{f})$ 
accumulation increased 17.94, 42.22, 75.44, 58.97 and $34.02 \%$ and azadirachtin production increased $0.53,31.53$, $160.65,207.37$ and $142.42 \%$ compared to the 2nd, 4th, 8th, 10th, and 12th days, respectively (Fig. 2b). The effect of different concentrations of yeast extract along with different sampling times is shown in Additional file 1: Table S1. The best conditions for induction of azadirachtin accumulation and production were an application of $25 \mathrm{mg} / \mathrm{L}$ for 2 days $(16.08 \mathrm{mg} / \mathrm{g} \mathrm{DW})$ and 4 days $(219.78 \mathrm{mg} / \mathrm{L})$, respectively. Under these conditions, the azadirachtin accumulation increased 462.24, 42.43, 66.11, 82.93 and $146.62 \%$ compared to the control, 50,100, 150, and $200 \mathrm{mg} / \mathrm{L}$ yeast extract the 2nd day of sampling and the azadirachtin production increased 302.16, 54.09, 96.23, 51.01 and 191.79\% compared to the control, 50, 100, 150 and $200 \mathrm{mg} / \mathrm{L}$ at same day, respectively (Additional file 1: Table S1).

\section{Model for predicting of azadirachtin accumulation and production}

The sampling times of 2, 4, 6, 8 and 10 days were chosen to RSM analysis and prediction of azadirachtin accumulation and production. The combined effects of different concentrations of yeast extract and sampling times were investigated by the response surface methodology using a central composite design (CCD). The specific interaction of different concentrations of yeast extract and sampling times with the measured and predicted response values of azadirachtin accumulation and production are shown in Table 1. In this study, the experiment No. 2 in application of $100 \mathrm{mg} / \mathrm{L}$ of yeast extract and sampling on the 2nd day had the highest amount of azadirachtin accumulation $(9.89 \mathrm{mg} / \mathrm{g} \mathrm{DW})$ and the experiment No. 13 in using of $150 \mathrm{mg} / \mathrm{L}$ of yeast extract and sampling on the 8th day had the lowest azadirachtin accumulation $(4.29 \mathrm{mg} / \mathrm{g} \mathrm{DW})$. Also, experiment No. 2 with an application of $100 \mathrm{mg} / \mathrm{L}$ of yeast extract and sampling time of 2 days had the highest azadirachtin production $(170.37 \mathrm{mg} / \mathrm{L})$ and experiment No. 3 with application of $50 \mathrm{mg} / \mathrm{L}$ yeast extract and sampling time of 8 days had the lowest azadirachtin production $(32.44 \mathrm{mg} / \mathrm{L})$.

Analysis of variance (ANOVA) of the results of the response surface model was presented in Table 4. In the analysis of variance of $C C D$, the coefficient of determination of the model for azadirachtin accumulation and production were 95.76 and $94.08 \%$, respectively; which indicates that these actual levels can correspond to the predicted levels. Also, the $p$-value of the models were significant and the proposed models were appropriate. Therefore, the following formulas were calculated to predict the azadirachtin accumulation and production using yeast extract and sampling times:

$$
\begin{aligned}
& \text { Azadirachtin accumulation }(\mathrm{mg} / \mathrm{g} \mathrm{DW}) \\
& =6.46+0.2452 \mathrm{~A}-1.36 \mathrm{~B}-1.09 \mathrm{AB} \\
& -0.4178 \mathrm{~A}^{2}+0.2269 \mathrm{~B}^{2} .
\end{aligned}
$$

$$
\begin{aligned}
& \text { Azadirachtin production }(\mathrm{mg} / \mathrm{L}) \\
& \begin{aligned}
= & 121.32+1.97 \mathrm{~A}-38.14 \mathrm{~B} \\
& +11.21 \mathrm{AB}-17.73 \mathrm{~A}^{2}-3.25 \mathrm{~B}^{2} .
\end{aligned}
\end{aligned}
$$

\section{Optimization of the response surface of azadriachtin accumulation and production}

The interaction between different yeast extract concentrations and different sampling times is shown in Fig. 2. Increasing the concentration of yeast extract along with increasing the exposure time to 6 days had a significant effect on the azadirachtin accumulation. The best yeast extract concentrations and sampling times for maximum azadirachtin accumulation were between 100 and $200 \mathrm{mg} / \mathrm{L}$ and 2-4 days. The highest amount of azadirachtin accumulation in this analysis was obtained in application of $100 \mathrm{mg} / \mathrm{L}$ of yeast extract after 2 days of sampling time. However, the optimal conditions for maximizing the azadirachtin accumulation $(13.607 \mathrm{mg} / \mathrm{g}$ DW) predicted two days after application of $245 \mathrm{mg} / \mathrm{L}$ of yeast extract (Fig. 2c, d). Also, the results indicated that azadirachtin production depends on sampling time. According to Fig. 2e, f, at all concentrations of yeast extract, azadirachtin production gradually decreases with increasing sampling time. The highest azadirachtin production is achieved by applying $0-150 \mathrm{mg} / \mathrm{L}$ of yeast extract and sampling time of 2-6 days. In this analysis, the highest azadirachtin production was 2 days after application of $100 \mathrm{mg} / \mathrm{L}$ of yeast extract, but it is predicted that the highest azadirachtin production with $71 \mathrm{mg} / \mathrm{L}$ is obtained by culturing of cell for 2 days at medium containing $190.50 \mathrm{mg} / \mathrm{L}$ of yeast extract.

\section{Mevalonic acid accumulation and production}

The HPLC chromatogram of mevalonic acid illustrated in Fig. 1e. The mevalonic acid accumulation and production were significantly changed under different yeast extract concentrations, sampling times, and their interactions (Table 3). Among the studied concentrations of yeast extract, $50 \mathrm{mg} / \mathrm{L}$ increased the accumulation of mevalonic acid compared to the control; and 25, 100, 150 and $200 \mathrm{mg} / \mathrm{L}$ of yeast extract decreased it in comparison to the control. With increasing the concentration of yeast extract in the culture medium from 0 to $25 \mathrm{mg} / \mathrm{L}$, the accumulation of mevalonic acid decreased, and then with increasing the concentration of yeast extract to $50 \mathrm{mg} / \mathrm{L}$ 
Table 2 Experimental and predicted values for sequalene accumulation and production optimized with central composite design (CCD)

\begin{tabular}{|c|c|c|c|c|c|c|}
\hline \multirow[t]{2}{*}{ Experiment } & \multirow{2}{*}{$\begin{array}{l}\text { Yeast extract (mg/L) } \\
\text { A }\end{array}$} & \multirow{2}{*}{$\begin{array}{l}\text { Sampling time } \\
\text { (day) (B) }\end{array}$} & \multicolumn{2}{|c|}{ Squalene accumulation (mg/g DW) } & \multicolumn{2}{|c|}{ Squalene production (mg/L) } \\
\hline & & & Actual value & Predicted value & Actual value & Predicted value \\
\hline 1 & $100(0)$ & $8(0)$ & 0.01 & 0.02 & 0.12 & 0.22 \\
\hline 2 & $100(0)$ & $8(0)$ & 0.01 & 0.02 & 0.11 & 0.22 \\
\hline 3 & $100(0)$ & $4(-2)$ & 0.13 & 0.13 & 2.21 & 2.29 \\
\hline 4 & $100(0)$ & $12(+2)$ & 0.01 & 0.01 & 0.09 & 0.11 \\
\hline 5 & $100(0)$ & $8(0)$ & 0.01 & 0.02 & 0.12 & 0.22 \\
\hline 6 & $50(-1)$ & $6(-1)$ & 0.14 & 0.11 & 2.15 & 1.81 \\
\hline 7 & $200(+2)$ & $8(0)$ & 0.02 & 0.01 & 0.16 & 0.00 \\
\hline 8 & $150(+1)$ & $6(-1)$ & 0.03 & 0.03 & 0.2 & 0.34 \\
\hline 9 & $100(0)$ & $8(0)$ & 0.01 & 0.02 & 0.11 & 0.22 \\
\hline 10 & $150(+1)$ & $10(+1)$ & 0.01 & 0.02 & 0.09 & 0.22 \\
\hline 11 & $100(0)$ & $8(0)$ & 0.03 & 0.02 & 0.41 & 0.22 \\
\hline 12 & $0(-2)$ & $8(0)$ & 0.06 & 0.08 & 0.75 & 1.01 \\
\hline 13 & $50(-1)$ & $10(+1)$ & 0.01 & 0.00 & 0.03 & 0.00 \\
\hline
\end{tabular}

Bold values indicated the highest amount

it was increased and with increasing the concentration of yeast extract form $50 \mathrm{mg} / \mathrm{L}$ to $200 \mathrm{mg} / \mathrm{L}$, its amount decreased again. The highest amount of mevalonic acid accumulation $(0.63 \mathrm{mg} / \mathrm{g} \mathrm{DW})$ was obtained at $50 \mathrm{mg} / \mathrm{L}$ yeast extract, which was $17.31 \%$ higher than the control and 48.71, 381.59, 265.15 and 353.86\% higher than the $25,100,150$ and $200 \mathrm{mg} / \mathrm{L}$ of yeast extract, respectively. Therefore, higher concentrations of yeast extract in the culture medium prevented the mevalonic acid accumulation. In relation to the production of mevalonic acid, it was observed that with increasing the yeast extract concentration from 0 to $25 \mathrm{mg} / \mathrm{L}$ the production of mevalonic acid decreased and with increasing the concentration of yeast extract from 25 to $50 \mathrm{mg} / \mathrm{L}$ it was increased; however, the difference between control and application of $50 \mathrm{mg} / \mathrm{L}$ yeast extract was not statistically significant. The highest mevalonic acid production $(8.45 \mathrm{mg} / \mathrm{L})$ was obtained at $50 \mathrm{mg} / \mathrm{L}$ of yeast extract. By adding $50 \mathrm{mg} / \mathrm{L}$ of yeast extract to culture medium, the mevalonic acid production increased 8.94, 47.06, 381.84, 302.82 and $424.19 \%$ compared to the control and 25, 100, 150 and $200 \mathrm{mg} / \mathrm{L}$ of yeast extract, respectively (Fig. 3a). Therefore, the application of moderate concentrations of yeast extract had a positive effect on the accumulation and production of mevalonic acid. By investigating the effect of sampling times, we founded that prolonged exposure of neem cell suspension culture with yeast extract reduces the mevalonic acid accumulation. The highest amount of mevalonic acid accumulation with an average of $0.78 \mathrm{mg} / \mathrm{g} \mathrm{DW}$ was observed on the second day of sampling. In general, two days after treatment the amount of mevalonic acid accumulation was 55.88, 79.76, 213.19, 915.48 and 5525.94\% higher than the 4th, 6 th, 8th, 10th, and 12th days, respectively. Also, between different sampling times, the highest mevalonic acid production $(9.95 \mathrm{mg} / \mathrm{L})$ was observed on the 2 nd day of sampling. By culturing of neem cells for 2 days, the mevalonic acid production was increased 23.63, 50.01, 359.17, 1724.97 and $11,214.56 \%$ compared to days $4,6,8,10$, and 12 , respectively (Fig. $3 \mathrm{~b}$ ). The interactions of yeast extract concentrations and sampling times showed that the highest mevalonic acid accumulation $(1.75 \mathrm{mg} / \mathrm{g} \mathrm{DW})$ and production $(23.77 \mathrm{mg} / \mathrm{L})$ were obtained two days after application of $50 \mathrm{mg} / \mathrm{L}$ yeast extract. In this conditions, mevalonic acid accumulation was 8.92, 212.90, 1954.11, 334.27 and $2716.13 \%$ higher than the control, 25, 100, 150 , and $200 \mathrm{mg} / \mathrm{L}$ of yeast extract and mevalonic acid production was 29.82, 216.93, 1801.60, 370.69 and $525.53 \%$ higher than the $25,50,75$, and $100 \mathrm{mg} / \mathrm{L}$ of yeast extract on same day (Additional file 1: Table S1).

\section{Model for predicting of mevalonic acid accumulation and production}

Based on the results, the sampling times of $2,4,6,8$, and 10 days were selected for RSM analysis and prediction of mevalonic acid accumulation and production. The specific interaction of different concentrations of yeast extract and sampling times with the measured and predicted response values of mevalonic acid accumulation and production is shown in Table 1. Experiment No. 10 (6 days after addition of $200 \mathrm{mg} / \mathrm{L}$ of yeast extract) had the highest amount of mevalonic acid accumulation 
Table 3 Analysis of variance of the effect of yeast extract and sampling times on measured indices in cell suspension culture of neem

\begin{tabular}{|c|c|c|c|c|c|c|}
\hline \multicolumn{2}{|l|}{ S.O.V } & \multirow{2}{*}{$\begin{array}{l}\text { Yeast extract (YE) } \\
5\end{array}$} & \multirow{2}{*}{$\begin{array}{l}\text { Sampling time (ST) } \\
5\end{array}$} & \multirow{2}{*}{$\begin{array}{l}\text { YE } \times S T \\
25\end{array}$} & \multirow{2}{*}{$\begin{array}{l}\text { Error } \\
72\end{array}$} & \multirow[t]{2}{*}{ CV (\%) } \\
\hline df & & & & & & \\
\hline \multirow[t]{8}{*}{ Mean of square } & Fresh cell weight & $93,350.82^{* *}$ & $179,438.79^{* *}$ & $33,712.14^{* *}$ & 2256.49 & 16.70 \\
\hline & Dry cell weight & $61.88^{* *}$ & $229.58^{* *}$ & $24.07^{* *}$ & 1.35 & 9.27 \\
\hline & $\begin{array}{l}\text { Azadirachtin accumu- } \\
\text { lation }\end{array}$ & $72.18^{* *}$ & $37.009^{* *}$ & $11.93^{* *}$ & 0.60 & 11.23 \\
\hline & $\begin{array}{l}\text { Azadirachtin produc- } \\
\text { tion }\end{array}$ & $10,274.50^{* *}$ & $27,632.98^{* *}$ & $3433.52^{* *}$ & 115.54 & 13.24 \\
\hline & $\begin{array}{l}\text { Mevalonic acid accu- } \\
\text { mulation }\end{array}$ & $0.88^{* *}$ & $1.47^{* *}$ & $0.51^{* *}$ & 0.007 & 24.67 \\
\hline & $\begin{array}{l}\text { Mevalonic acid pro- } \\
\text { duction }\end{array}$ & $177.95^{* *}$ & $314.43^{* *}$ & $108.41^{* *}$ & 1.51 & 26.89 \\
\hline & $\begin{array}{l}\text { Squalene accumula- } \\
\text { tion }\end{array}$ & $0.006^{* *}$ & $0.02^{* *}$ & $0.006^{* *}$ & 0.00003 & 12.55 \\
\hline & Squalene production & $2.30^{* *}$ & $6.87^{* *}$ & $1.98^{* *}$ & 0.02 & 21.88 \\
\hline
\end{tabular}

* and ${ }^{* *}$ significant at $5 \%$ and $1 \%$ probability level, respectively

$(0.51 \mathrm{mg} / \mathrm{g} \mathrm{DW})$ and experiment No. 2 (two days after application of $100 \mathrm{mg} / \mathrm{L}$ yeast extract) had the lowest of mevalonic acid accumulation. Also, experiment No. 12 with the application of $100 \mathrm{mg} / \mathrm{L}$ of yeast extract for 6 days had the highest amount of mevalonic acid production $(6.97 \mathrm{mg} / \mathrm{g} D W)$ and experiment No. 2 with using $100 \mathrm{mg} / \mathrm{L}$ of yeast extract for two days produced the lowest of mevalonic acid production. Analysis of variance results revealed that the coefficient of determination $\left(\mathrm{R}^{2}\right)$ of the model for mevalonic acid accumulation and production were 91.67 and $87.53 \%$, respectively; which indicates that 91.67 and $87.53 \%$ of the actual value can correspond to the predicted value. Also, the $p$-value of the models were significant and the proposed models were appropriate (Table 4). Therefore, the following formulas were calculated to predict the mevalonic acid accumulation and production using yeast extract and sampling times:

$$
\begin{aligned}
& \text { Mevalonic acid accumulation }(\mathrm{mg} / \mathrm{g} \mathrm{DW}) \\
& =0.2513+0.0569 \mathrm{~A}+0.0199 \mathrm{~B}-0.0289 \mathrm{AB} \\
& \quad+0.0313 \mathrm{~A}^{2}-0.0364 \mathrm{~B}^{2} . \\
& \text { Mevalonic acid production }(\mathrm{mg} / \mathrm{L}) \\
& =5.26-0.0101 \mathrm{~A}+0.0210 \mathrm{~B}-0.2599 \mathrm{AB} \\
& \quad+0.0543 \mathrm{~A}^{2}-1.02 \mathrm{~B}^{2} .
\end{aligned}
$$

Optimization of the response surface of mevalonic acid accumulation and production

The interaction between different yeast extract concentrations and different sampling times is shown in Fig. 3. The results showed that yeast extract concentration is the most important factor. Accordingly, gradual increases in the concentration of yeast extract lead to a decrease in the accumulation of mevalonic acid in the neem cell suspension culture. Therefore, in this analysis, the highest amount of accumulation of mevalonic acid was observed at their highest level. Depending on the concentration of yeast extract, sampling time increased or decreased the accumulation of mevalonic acid. According to Fig. 3c, d, the highest amount of mevalonic acid accumulation was obtained 6 days after applying $200 \mathrm{mg} / \mathrm{L}$ of yeast extract, but it is predicted that the highest amount of mevalonic acid accumulation with the amount of $0.50 \mathrm{mg} / \mathrm{g}$ DW was obtained by culture of the cells for 4.96 days in medium containing $200 \mathrm{mg} / \mathrm{L}$ of yeast extract. Also, according to the results of this analysis, the production of mevalonic acid depends on the sampling time. At different concentrations of yeast extract, increasing the duration of cell suspension culture exposure to yeast extract increased the amount of mevalonic production from 2 to 6 days and then decreased. The highest mevalonic acid production was obtained by exposing the cell suspension to $100 \mathrm{mg} / \mathrm{L}$ of yeast extract for 6 days. The optimal condition for maximizing the mevalonic acid production is predicted to be a cell suspension culture without yeast extract after 6.54 days, which can produces $5.57 \mathrm{mg} / \mathrm{L}$ mevalonic acid.

\section{Squalene accumulation and production}

The HPLC chromatogram of squalene is illustrated in Fig. 1f. The results showed that different concentrations of yeast extract, sampling times, and their interactions had a significant effect on squalene accumulation and production (Table 3). The study of squalene accumulation in cell suspension culture in the presence of yeast extract revealed that yeast extract inhibited squalene accumulation. Increasing the concentration of yeast 

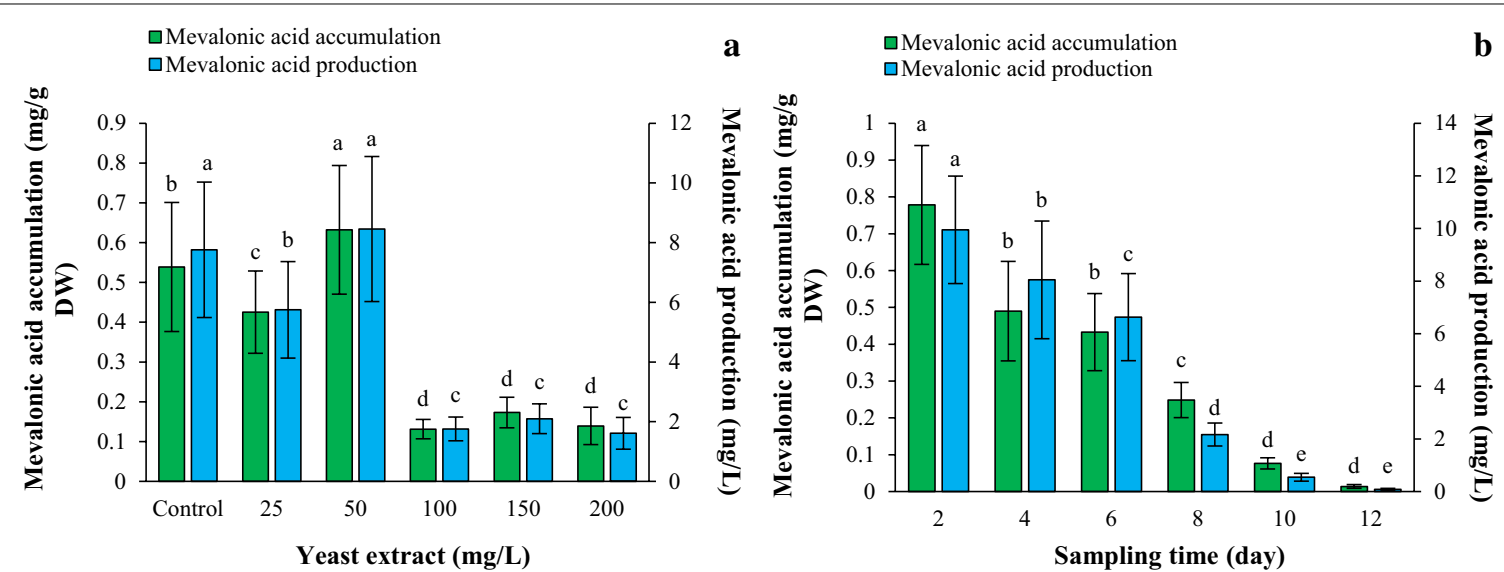

$\square$ Mevalonic acid accumulation
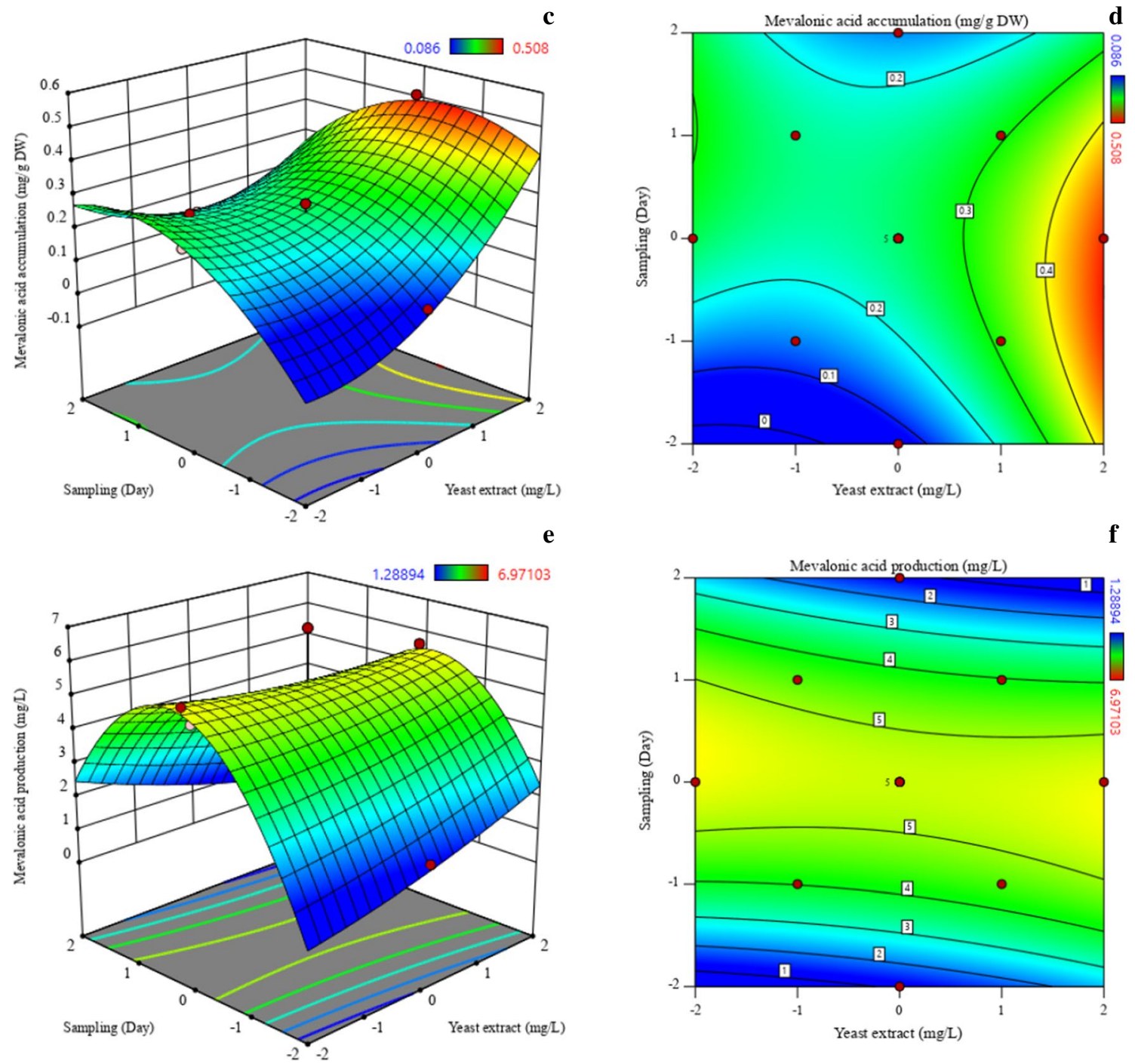

Fig. 3 The effect of different concentrations of yeast extract and sampling times $(\mathbf{a}, \mathbf{b})$ and response surface and contour plots for mevalonic acid accumulation (c, $\mathbf{d})$ and mevalonic acid production (e, $\mathbf{f})$ 
extract in the culture medium the accumulation of squalene was reduced. With increasing the yeast extract concentration from 25 to $50 \mathrm{mg} / \mathrm{L}$, the squalene accumulation was increased and then decreased. The highest squalene accumulation $(0.07 \mathrm{mg} / \mathrm{g}$ DW) between different concentrations of yeast extract was obtained at the control condition. With using 25, 50, 100, 150, and $200 \mathrm{mg} / \mathrm{L}$ yeast extract squalene accumulation decreased $59.70,5.97,35.82,42.27$ and $64.17 \%$ than control, respectively. Analysis the data about squalene production revealed that the application of $50 \mathrm{mg} / \mathrm{L}$ of yeast extract increased squalene production compared to the control and application of $25,100,150$, and $200 \mathrm{mg} / \mathrm{L}$ decreased it. Among different concentrations of yeast extract, the highest production of squalene $(1.13 \mathrm{mg} / \mathrm{L})$ was obtained at $50 \mathrm{mg} / \mathrm{L}$, which was $14.85,227.71,66.62,123.72$ and $398.77 \%$ higher compared to the control and 25, 100, 150, and $200 \mathrm{mg} / \mathrm{L}$, respectively (Fig. 4a). Between different sampling times, the highest amount of squalene accumulation was $0.10 \mathrm{mg} / \mathrm{g}$ DW obtained on the 4th day of sampling time. In general, 4 days after yeast extract treatment the amount of squalene accumulation comparing to $2,6,8,10$ and 12 days was 547.87, 44.95, 363.76, 149.67 and $361.09 \%$ higher, respectively. Investigation of different sampling times showed that during the first 4 days, the production of squalene in the cell suspension culture of neem was increased and then was decreased on further days. The highest amount of squalene production $(1.74 \mathrm{mg} / \mathrm{L})$ was observed on the 4 th day of sampling. So that, on the 4th day of sampling time the amount of squalene production in comparing to the $2 \mathrm{nd}$, 6th, 8 th, 10 th, and 12th days was $732.07,68.63,748.53,343.38$ and $474.63 \%$ higher, respectively (Fig. 4b). Further study of squalene accumulation and production was performed using the simultaneous examination of different concentrations of yeast extract and sampling times. In this context, the results showed that 4 days after application of $50 \mathrm{mg} / \mathrm{L}$ of yeast extract the highest amount of squalene accumulation $(0.22 \mathrm{mg} / \mathrm{g} \mathrm{DW})$ and production $(4.53 \mathrm{mg} / \mathrm{L})$ were obtained, which were $283.93,1333.3$, 69.29, 41.45 and 923.81\%; and 377.43, 1817.79, 105.54, 99.47 and $1739.84 \%$ higher in comparing to the control, $25,100,150$, and $200 \mathrm{mg} / \mathrm{L}$, respectively (Additional file 1: Table S1).

\section{Model for predicting of squalene accumulation and production}

The sampling times of $4,6,8,10$, and 12 days were selected for RSM analysis and prediction of squalene accumulation and production. The experimental and predicted values of yeast extract-induced squalene accumulation are shown in Table 2. Experiment No. 6 (6 days after application of $50 \mathrm{mg} / \mathrm{L}$ yeast extract) had the highest squalene accumulation $(0.14 \mathrm{mg} / \mathrm{g} \mathrm{DW})$ and experiment No. 10 (150 mg/L of yeast extract after 10 days) had the lowest squalene production $(0.01 \mathrm{mg} / \mathrm{g} \mathrm{DW})$. Experiment No. 3 with an application of $100 \mathrm{mg} / \mathrm{L}$ of yeast extract and sampling time of 4 days had maximum squalene production $(2.21 \mathrm{mg} / \mathrm{L})$ and experiment No. 13 with an application of $50 \mathrm{mg} / \mathrm{L}$ of yeast extract and sample time of 10 days had the lowest squalene production. The results of the analysis of variance of central composite design showed that the coefficient of determination $\left(R^{2}\right)$ of the model is $94.20 \%$ for squalene accumulation and $94.48 \%$ for squalene production. This indicates that 94.20 and $94.48 \%$ of the actual value of squalene accumulation and production correspond to the predicted value. Also, the $p$-value of the models were significant for squalene accumulation and production, which indicates the suitability of the models (Table 4). Therefore, mathematical models which were obtained to predict the squalene accumulation and production under yeast extract elicitation were as following:

$$
\begin{aligned}
& \text { Squalene accumulation }(\mathrm{mg} / \mathrm{g} \mathrm{DW}) \\
& \begin{array}{l}
= \\
\quad \\
\quad+0199-0.0169 \mathrm{~A}-0.0304 \mathrm{~B}+0.0274 \mathrm{AB}
\end{array} \\
& \text { Squalene production }(\mathrm{mg} / \mathrm{L}) \\
& =0.2150-0.2509 \mathrm{~A}-0.5438 \mathrm{~B}+0.4834 \mathrm{AB} \\
& \quad+0.0725 \mathrm{~A}^{2}+0.2466 \mathrm{~B}^{2} .
\end{aligned}
$$

\section{Optimization of the response surface of squalene accumulation and production}

Figure 4 shows the interaction between different yeast extract concentrations and different sampling times. According to the results of the response surface methodology, the squalene accumulation depends on the concentration of yeast extract and the sampling time. The yeast extract concentration is the most important parameter and with increasing that the squalene accumulation has reached a minimum. In the different concentrations of yeast extract except for $200 \mathrm{mg} / \mathrm{L}$, the accumulation of squalene decreased on over times. At $200 \mathrm{mg} / \mathrm{L}$ yeast extract, the squalene accumulation was decreased till the tenth day of sampling and then was increased. Therefore, depending on the concentration of yeast extract, sampling time can have a positive or negative effect on squalene accumulation. Based on this analysis results, the highest amount of squalene accumulation was obtained 6 days after application of $50 \mathrm{mg} / \mathrm{L}$ yeast extract, but the prediction results showed that the highest squalene accumulation can be obtained at free-yeast extract medium after 4 days, which can accumulates $0.30 \mathrm{mg} / \mathrm{g} \mathrm{DW}$ of 


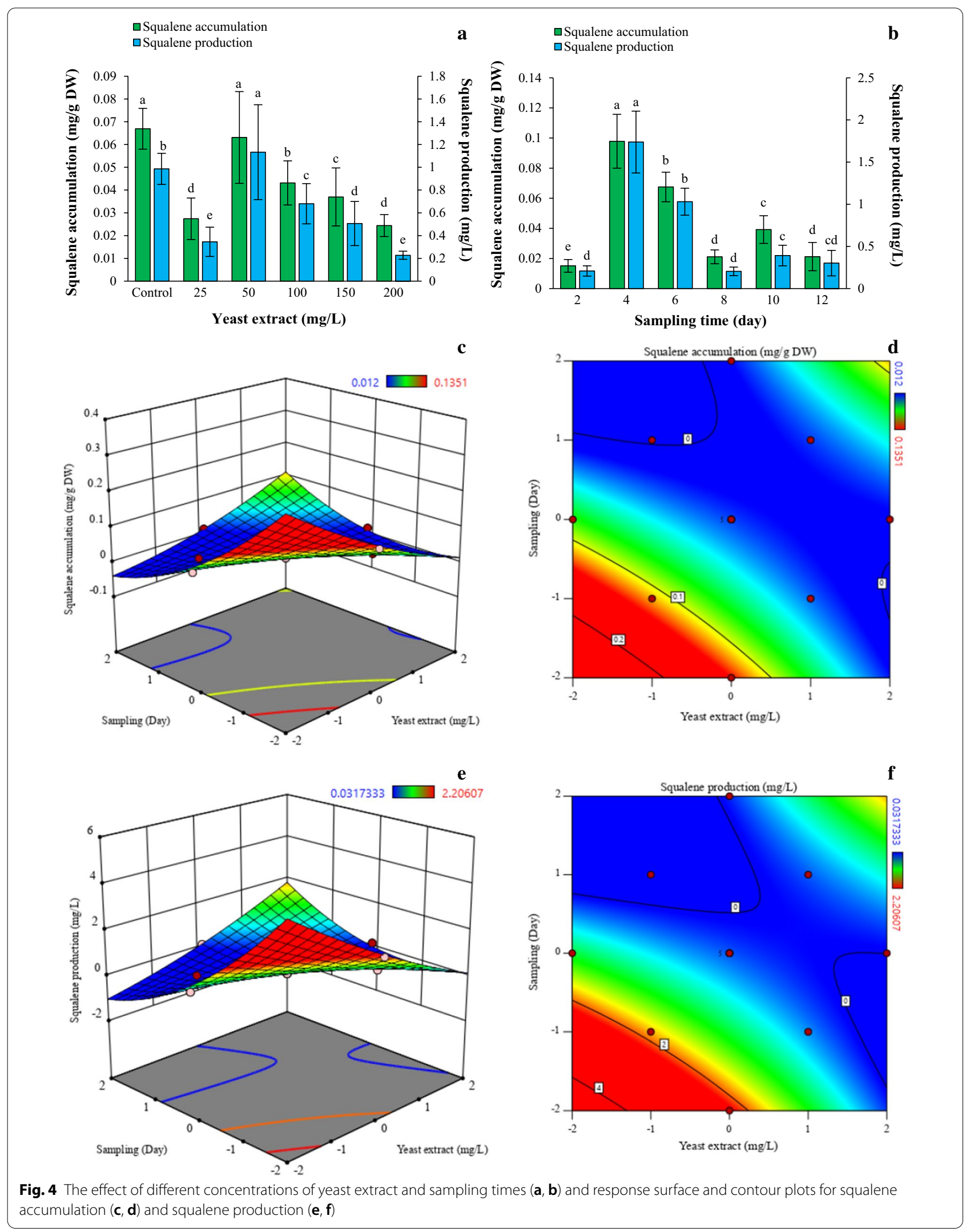


Table 4 Analysis of variance of azadirachtin, mevalonic acid and squalene accumulation and production in the central composite design under influence of yeast extract and sampling times

\begin{tabular}{|c|c|c|c|c|c|c|c|}
\hline \multirow[t]{2}{*}{ Source } & \multirow[t]{2}{*}{$d f$} & \multicolumn{6}{|l|}{ Mean of square } \\
\hline & & $\begin{array}{l}\text { Azadirachtin } \\
\text { accumulation }\end{array}$ & $\begin{array}{l}\text { Azadirachtin } \\
\text { production }\end{array}$ & $\begin{array}{l}\text { Mevalonic acid } \\
\text { accumulation }\end{array}$ & $\begin{array}{l}\text { Mevalonic acid } \\
\text { production }\end{array}$ & $\begin{array}{l}\text { Squalene } \\
\text { accumulation }\end{array}$ & $\begin{array}{l}\text { Squalene } \\
\text { production }\end{array}$ \\
\hline Model & 5 & $6.95^{\mathrm{s}}$ & $5058.59^{s}$ & $0.02^{\mathrm{s}}$ & $5.46^{\mathrm{s}}$ & $0.004^{s}$ & $1.33^{\mathrm{s}}$ \\
\hline A: Yeast extract & 1 & $0.72^{\text {ns }}$ & $46.34^{\mathrm{ns}}$ & $0.04^{s}$ & $0.001^{\mathrm{ns}}$ & $0.003^{\mathrm{s}}$ & $0.75^{\mathrm{s}}$ \\
\hline B: Sampling time & 1 & $22.31^{\mathrm{s}}$ & $17,458.30^{s}$ & $0.005^{\text {ns }}$ & $0.005^{\text {ns }}$ & $0.01^{\mathrm{s}}$ & $3.55^{\mathrm{s}}$ \\
\hline$A B$ & 1 & $4.76^{5}$ & $502.37^{\mathrm{ns}}$ & $0.003^{\text {ns }}$ & $0.27^{\mathrm{ns}}$ & $0.003^{s}$ & $0.93^{\mathrm{s}}$ \\
\hline$A^{2}$ & 1 & $4.00^{5}$ & $7206.08^{s}$ & $0.02^{5}$ & $0.07^{\mathrm{ns}}$ & $0.001^{\text {ns }}$ & $0.12^{\mathrm{ns}}$ \\
\hline$B^{2}$ & 1 & $1.18^{\mathrm{ns}}$ & $241.38^{\text {ns }}$ & $0.03^{5}$ & $24.06^{s}$ & $0.004^{\mathrm{s}}$ & $1.39^{5}$ \\
\hline Residual & 7 & 0.22 & 227.39 & 0.002 & 0.56 & 0.0002 & 0.06 \\
\hline Lack of fit & 3 & $0.41^{\mathrm{ns}}$ & $436.22^{\text {ns }}$ & $0.001^{\text {ns }}$ & $0.28^{\mathrm{ns}}$ & $0.0003^{\text {ns }}$ & $0.10^{\mathrm{ns}}$ \\
\hline Pure error & 4 & 0.08 & 70.77 & 0.002 & 0.76 & 0.0001 & 0.02 \\
\hline$R^{2}(\%)$ & & 95.76 & 94.08 & 91.67 & 87.53 & 94.20 & 94.48 \\
\hline $\mathrm{R}_{2}^{\mathrm{adj}}(\%)$ & & 92.73 & 89.85 & 85.71 & 78.63 & 90.05 & 90.55 \\
\hline Adeq precision & & 18.94 & 14.89 & 15.79 & 8.65 & 14.49 & 15.84 \\
\hline
\end{tabular}

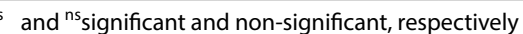

squalene. Also, increasing the yeast extract concentration during low exposure periods reduced squalene production, but increasing yeast extract concentration at high exposure times enhanced squalene production. According to Fig. 4e, f, it can be said that using $0-100 \mathrm{mg} / \mathrm{L}$ of yeast extract for 4-8 days can produce an acceptable amount of squalene. It is predicted that the highest amount of squalene production is achieved by long-term exposure to high concentrations of yeast extract.

\section{qRT-PCR analysis of SQS1 and MOF1 genes expression}

The qRT-PCR analysis presented relative gene expression of SQS1 gene was significantly increased $68.96 \%$ at 4 days application of $150 \mathrm{mg} / \mathrm{L}$ of yeast extract compared with the control cells after 12 days. But, after the addition of 25,50 and $100 \mathrm{mg} / \mathrm{L}$ of yeast extract for 2 days, and $200 \mathrm{mg} / \mathrm{L}$ of yeast extract for 12 days, the relative expression of SQS1 gene decreased 73.26, 74.49, 38.29 and $73.53 \%$, respectively compared to the control after 12 days. Also, the application of yeast extract significantly up-regulated $M O F 1$ gene. The highest relative expression of the MOF1 gene observed by addition $25 \mathrm{mg} / \mathrm{L}$ yeast extract for 2 days, which was 52.41, 14.46, 26.02, 22.51 and $39.90 \%$ higher than control on 12 days, $50 \mathrm{mg} / \mathrm{L}$ of yeast extract on 2 days, $100 \mathrm{mg} / \mathrm{L}$ of yeast extract on 2 days, $150 \mathrm{mg} / \mathrm{L}$ of yeast extract on 4 days, and $200 \mathrm{mg} / \mathrm{L}$ of yeast extract on 12 days (Fig. 5).

\section{Discussion}

Many researchers have been reported that the use of elicitors is effective in cell growth and increasing bioactive compounds. The age of the cell culture, the duration of exposure to the elicitor, and the type of elicitor have a very effective role in increasing the effect of the elicitors (Açıkgöz 2020; Nazir et al. 2019). Elicitor concentration is an important factor for the elicitation process and the optimum level depends on the plant species (Vasconsuelo and Boland 2007). The studies showed that high concentrations of elicitors trigger the hypersensitive response and leading to cell death (Park et al. 2020). Yeast extract is applied to enhance growth and secondary metabolites production in the cell and hairy root cultures of different plants such as Artemisia annua (Putalun et al. 2007) and Salvia miltiorrhiza (Yan et al. 2006). In this study, the highest fresh and dry cell weight was obtained 6 days after the addition of $100 \mathrm{mg} / \mathrm{L}$ yeast extract. The positive effect of using yeast extract on cell and plant growth and increasing biomass has been reported in some studies. Krstić-Milošević et al. (2017) reported that biotic elicitors such as yeast extract improved root growth and biomass production in Gentiana dinarica. Bayraktar et al. (2016) enhanced biomass production of Stevia rebaudiana by yeast extract.

The highest azadirachtin accumulation and production were obtained by using $25 \mathrm{mg} / \mathrm{L}$ of yeast extract on 2 and 4 days, maximum mevalonic acid accumulation and production observed 2 days after $50 \mathrm{mg} / \mathrm{L}$ of yeast extract addition and the highest amount of squalene accumulation and production were achieved 4 days after application of $50 \mathrm{mg} / \mathrm{L}$ of yeast extract. The stimulating effect of yeast extract on the isoflavonoid production in Pueraria candollei hairy root cultures was reported (Udomsuk et al. 2011). Rani et al. (2020) showed that the utility of yeast extract enhances daidzein and genistein production 


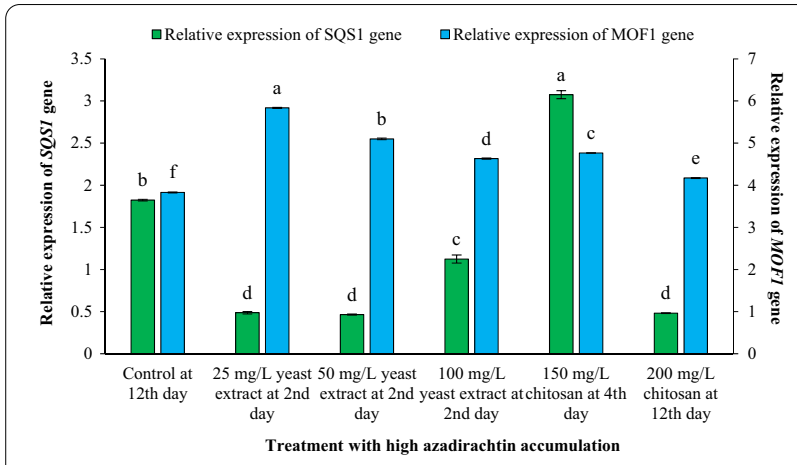

Fig. 5 Relative expression profile of SQS1 and MOF1 genes normalized with 185 ribosomal RNA as an internal control

in the cell culture of Pueraria candollei. Sharma and Agrawal (2018) produced $544.60 \mu \mathrm{g} / \mathrm{g} \mathrm{DW}$ plumbagin in root cultures of plumbago zeylanica L. by using $100 \mathrm{mg} / \mathrm{L}$ of yeast extract. Elicitation of Helianthus tuberosus L. with $0.25 \mathrm{mg} / \mathrm{L}$ of yeast extract increased inulin content 1.18-fold compared to control (Ma et al. 2017). Park et al. (2016) observed the highest amount of rosmarinic acid $(4.98 \mathrm{mg} / \mathrm{g}$ ) by using $750 \mathrm{mg} / \mathrm{L}$ of yeast extract in Agastache rugosa cell culture. Szopa et al. (2018) increased lignan production in micro-shoot cultures of Schisandra chinensis by elicitation with $5000 \mathrm{mg} / \mathrm{L}$ of yeast extract on the first day of the growth period and with 1000 and $3000 \mathrm{mg} / \mathrm{L}$ on the 20th day.

Elicitors activate the plant's defense response, causing consecutive cellular and molecular events and activating biosynthetic genes involved in the production of secondary metabolites (Jiao et al. 2016). Various studies have shown the upregulated accumulation of different secondary metabolites by different elicitors such as yeast extract (van der Heijden et al. 1989; Yoon et al. 2000). For example, in the hairy root cultures of Artemisia annua L. application of fungal elicitors enhanced artemisinin production and upregulate expression profile of mevalonate and methylerythritol phosphate biosynthetic genes (Ahlawat et al. 2014). These results are consistent with our findings. In this study, the qRT-PCR analysis showed the maximum relative gene expression of SQS1 and MOF1 obtained by application of $150 \mathrm{mg} / \mathrm{L}$ of yeast extract for 4 days and $25 \mathrm{mg} / \mathrm{L}$ of yeast extract for 2 days, respectively. In cell cultures of Uncaria tomentosa and Tobernamontana divaricate, the activities of enzymes involved in triterpenoid biosynthesis such as IDI and SS are stimulated by elicitors (Flores-Sánchez et al. 2002; Fulton et al. 1994). Ge and Wu (2005) reported that yeast elicitor stimulated HMGR activity in Salvia miltiorrhiza hairy root cultures. In cell culture of $A$. rugosa the transcript levels of HPPR under yeast extract treatment were higher than the control (Park et al. 2016).
In conclusion, this is the first study on the optimization of yeast extract and sampling time for the production of azadirachtin, mevalonic acid, and squalene in the cell suspension cultures and investigation of SQS1 and MOF1 genes expression of neem. Central-composite design (CCD) of Response Surface Methodology (RSM) optimized the effects of yeast extract and sampling time for maximum accumulation and production of azadirachtin, mevalonic acid, and squalene. These results showed that advancement in tissue culture techniques and prediction methods could be applied for the production and enhancement of secondary metabolites. Also, neem cell suspension culture is a suitable strategy for the commercial production of secondary metabolites in in vitro conditions. In addition, in the future, methods for predicting optimal conditions for maximum production of secondary metabolites can reduce the production times and costs of new drug compounds.

\section{Supplementary Information}

The online version contains supplementary material available at https://doi. org/10.1186/s13568-021-01203-x.

Additional file 1: Table S1 Effect of different concentrations of yeast extract and sampling times on measured indices of cell suspension culture of neem.

\section{Acknowledgements}

This work was supported by Imam Khomeini International University (IKIU). Special thanks to Dr. Jafar Ahmadi for the technical support.

\section{Authors' contributions}

RF wrote the manuscript and carried out experiments and data analysis. GG supervised the experiment and conducted an English revision. Both authors approved its final version.

\section{Availability of data and materials}

All data generated or analysed during this study are included in this published article and its supplementary information files.

\section{Declarations}

Ethics approval and consent to participate

This article does not contain any studies with human participants or animals performed by any of authors.

\section{Competing interests}

The authors declare no competing interest.

Received: 28 December 2020 Accepted: 7 March 2021

Published online: 17 March 2021

\section{References}

Abd El-Salam M, Mekky H, El-Naggar EMB, Ghareeb D, El-Demellawy M, El-Fiky F (2015) Hepatoprotective properties and biotransformation of berberine and berberrubine by cell suspension cultures of Dodonaea viscosa and Ocimum basilicum. S Afr J Bot 97:191-195. https://doi.org/10.1016/j.sajb. 2015.01.005

Açıkgöz MA (2020) Establishment of cell suspension cultures of Ocimum basilicum L. and enhanced production of pharmaceutical active ingredients. Ind Crop Prod 148:112278. https://doi.org/10.1016/j.indcrop.2020.112278 
Ahlawat S, Saxena P, Alam P, Wajid S, Abdin MZ (2014) Modulation of artemisinin biosynthesis by elicitors, inhibitor, and precursor in hairy root cultures of Artemisia annua L. J Plant Interact 9:811-824. https://doi.org/ 10.1080/17429145.2014.949885

Alzohairy MA (2016) Therapeutics role of Azadirachta indica (neem) and their active constituents in diseases prevention and treatment. Evid-Based Compl Alt 2016:7382506. https://doi.org/10.1155/2016/7382506

Baenas N, García-Viguera C, Moreno DA (2014) Elicitation: a tool for enriching the bioactive composition of foods. Molecules 19:13541-13563. https:// doi.org/10.3390/molecules190913541

Bayraktar M, Naziri E, Akgun IH, Karabey F, Ilhan E, Akyol B, Bedir E, Gurel A (2016) Elicitor induced stevioside production, in vitro shoot growth, and biomass accumulation in micropropagated Stevia rebaudiana. Plant Cell Tiss Org 127:289-300. https://doi.org/10.1007/s11240-016-1049-7

Borkotoky S, Banerjee M (2020) A computational prediction of SARS-CoV-2 structural protein inhibitors from Azadirachta indica (Neem). J Biomol Struct Dyn 1-11. https://doi.org/10.1080/07391102.2020.1774419

Cheng Q, He Y, Li G, Liu Y, Gao W, Huang L (2013) Effects of combined elicitors on tanshinone metabolic profiling and SmCPS expression in Salvia miltiorrhiza hairy root cultures. Molecules 18:7473-7485. https://doi.org/10. 3390/molecules18077473

Farjaminezhad R, Garoosi G-a (2019) New biological trends on cell and callus growth and azadirachtin production in Azadirachta indica. 3 Biotech 9:309. https://doi.org/10.1007/s13205-019-1836-z

Farjaminezhad R, Garoosi G-a (2020) Establishment of green analytical method for ultrasound-assisted extraction of azadirachtin, mevalonic acid and squalene from cell suspension culture of Azadirachta indica using response surface methodology. Ind Crop Prod 144:111946. https://doi. org/10.1016/j.indcrop.2019.111946

Flores-Sánchez IJ, Ortega-López J, Montes-Horcasitas MdC, Ramos-Valdivia AC (2002) Biosynthesis of sterols and triterpenes in cell suspension cultures of Uncaria tomentosa. Plant Cell Physiol 43:1502-1509. https://doi.org/10. 1093/pcp/pcf181

Fulton DC, Kroon PA, Threlfall DR (1994) Enzymological aspects of the redirection of terpenoid biosynthesis in elicitor-treated cultures of Tabernaemontana divaricata. Phytochemistry 35:1183-1186. https://doi.org/10.1016/ S0031-9422(00)94818-0

Ge X, Wu J (2005) Tanshinone production and isoprenoid pathways in Salvia miltiorrhiza hairy roots induced by $\mathrm{Ag}^{+}$and yeast elicitor. Plant Sci 168:487-491. https://doi.org/10.1016/j.plantsci.2004.09.012

Godoy-Hernández G, Vázquez-Flota FA (2006) Growth measurements. In: Loyola-Vargas VM, Vázquez-Flota F (eds) Plant cell culture protocols. Humana Press, Totowa, pp 51-58. https://doi.org/10.1385/1-59259-959-1:051

Gonçalves S, Mansinhos I, Rodríguez-Solana R, Pérez-Santín E, Coelho N, Romano A (2019) Elicitation improves rosmarinic acid content and antioxidant activity in Thymus lotocephalus shoot cultures. Ind Crop Prod 137:214-220. https://doi.org/10.1016/j.indcrop.2019.04.071

Guízar-González C, Monforte-González M, Vázquez-Flota F (2016) Yeast extract induction of sanguinarine biosynthesis is partially dependent on the octadecanoic acid pathway in cell cultures of Argemone mexicana L., the Mexican poppy. Biotechnol Lett 38:1237-1242. https://doi.org/10.1007/ s10529-016-2095-2

Jiao J, Gai Q-Y, Wang W, Luo M, Zu Y-G, Fu Y-J, Ma W (2016) Enhanced astragaloside production and transcriptional responses of biosynthetic genes in Astragalus membranaceus hairy root cultures by elicitation with methyl jasmonate. Biochem Eng J 105:339-346. https://doi.org/10.1016/j.bej. 2015.10.010

Karalija E, Zeljković SĆ, Parić A (2020) Harvest time-related changes in biomass, phenolics and antioxidant potential in Knautia sarajevensis shoot cultures after elicitation with salicylic acid and yeast. Vitro Cell Dev-PI 56:177-183. https://doi.org/10.1007/s11627-019-10028-0

Krstić-Milošević D, Janković T, Uzelac B, Vinterhalter D, Vinterhalter B (2017) Effect of elicitors on xanthone accumulation and biomass production in hairy root cultures of Gentiana dinarica. Plant Cell Tiss Org 130:631-640. https://doi.org/10.1007/s11240-017-1252-1

Livak KJ, Schmittgen TD (2001) Analysis of relative gene expression data using real-time quantitative PCR and the $2-\triangle \triangle C T$ method. Methods 25:402-408. https://doi.org/10.1006/meth.2001.1262

Ma C, Zhou D, Wang H, Han D, Wang Y, Yan X (2017) Elicitation of Jerusalem artichoke (Helianthus tuberosus L.) cell suspension culture for enhancement of inulin production and altered degree of polymerisation. J Sci Food Agric 97:88-94. https://doi.org/10.1002/jsfa.7686

Mäkelä M (2017) Experimental design and response surface methodology in energy applications: a tutorial review. Energ Convers Manage 151:630640. https://doi.org/10.1016/j.enconman.2017.09.021

Mbah AU, Udeinya IJ, Shu EN, Chijioke CP, Nubila T, Udeinya F, Muobuike A, Mmuobieri A, Obioma MS (2007) Fractionated neem leaf extract is safe and increases cd4+ cell levels in HIV/AIDS patients. Am J Ther 14:369-374. https://doi.org/10.1097/MJT.0b013e3180a72199

Menezes Maciel Bindes M, Hespanhol Miranda Reis M, Luiz Cardoso V, Boffito DC (2019) Ultrasound-assisted extraction of bioactive compounds from green tea leaves and clarification with natural coagulants (chitosan and Moringa oleifera seeds). Ultrason Sonochem 51:111-119. https://doi.org/ 10.1016/j.ultsonch.2018.10.014

Murthy HN, Lee E-J, Paek K-Y (2014) Production of secondary metabolites from cell and organ cultures: strategies and approaches for biomass improvement and metabolite accumulation. Plant Cell Tiss Organ Cult 118:1-16. https://doi.org/10.1007/s11240-014-0467-7

Namdeo A (2007) Plant cell elicitation for production of secondary metabolites: a review. Pharmacogn Rev 1:69-79

Nazir M, Tungmunnithum D, Bose S, Drouet S, Garros L, Giglioli-Guivarc'h N, Abbasi BH, Hano C, (2019) Differential production of phenylpropanoid metabolites in callus cultures of Ocimum basilicum L. with distinct in vitro antioxidant activities and in vivo protective effects against UV stress. J Agric Food Chem 67:1847-1859. https://doi.org/10.1021/acs.jafc.8b05647

Park WT, Arasu MV, AI-Dhabi NA, Yeo SK, Jeon J, Park JS, Lee SY, Park SU (2016) Yeast extract and silver nitrate induce the expression of phenylpropanoid biosynthetic genes and induce the accumulation of rosmarinic acid in Agastache rugosa cell culture. Molecules 21:426. https://doi.org/10.3390/ molecules21040426

Park YJ, Kim JK, Park SU (2020) Yeast extract improved biosynthesis of astragalosides in hairy root cultures of Astragalus membranaceus. Prep Biochem Biotech 1-8. https://doi.org/10.1080/10826068.2020.1830415

Putalun W, Luealon W, De-Eknamkul W, Tanaka H, Shoyama Y (2007) Improvement of artemisinin production by chitosan in hairy root cultures of Artemisia annua L. Biotechnol Lett 29:1143-1146. https://doi.org/10. 1007/s10529-007-9368-8

Rafiq M, Dahot MU (2010) Callus and azadirachtin related limonoids production through in vitro culture of neem (Azadirachta indica A. Juss). Afr J Biotechnol 9

Ramachandra Rao S, Ravishankar GA (2002) Plant cell cultures: chemical factories of secondary metabolites. Biotechnol Adv 20:101-153. https:// doi.org/10.1016/S0734-9750(02)00007-1

Ramirez-Estrada K, Vidal-Limon H, Hidalgo D, Moyano E, Golenioswki M, Cusidó RM, Palazon J (2016) Elicitation, an effective strategy for the biotechnological production of bioactive high-added value compounds in plant cell factories. Molecules 21:182. https://doi.org/10.3390/molec ules21020182

Rani D, Meelaph T, De-Eknamkul W, Vimolmangkang S (2020) Yeast extract elicited isoflavonoid accumulation and biosynthetic gene expression in Pueraria candollei var. mirifica cell cultures. Plant Cell Tiss Organ Cult 141:661-667. https://doi.org/10.1007/s11240-020-01809-2

Roy S, Bhattacharyya P (2020) Possible role of traditional medicinal plant Neem (Azadirachta indica) for the management of COVID-19 infection. Int J Res Pharm Sci 11:122-125. https://doi.org/10.26452/ijrps.v1 1iSPL1.2256

Sarkar L, Putchala RK, Safiriyu AA, Das Sarma J (2020) Azadirachta indica A. Juss ameliorates mouse hepatitis virus-induced neuroinflammatory demyelination by modulating cell-to-cell fusion in an experimental animal model of multiple sclerosis. Front Cell Neurosci 14. https://doi.org/10.3389/fncel. 2020.00116

Sharma U, Agrawal V (2018) In vitro shoot regeneration and enhanced synthesis of plumbagin in root callus of Plumbago zeylanica L. an important medicinal herb. Vitro Cell Dev-PI 54:423-435. https://doi.org/10.1007/ s11627-018-9889-y

Singh T, Sharma U, Agrawal V (2020) Isolation and optimization of plumbagin production in root callus of Plumbago zeylanica L. augmented with chitosan and yeast extract. Ind Crop Prod 151:112446. https://doi.org/10. 1016/j.indcrop.2020.112446

Szopa A, Kokotkiewicz A, Król A, Luczkiewicz M, Ekiert H (2018) Improved production of dibenzocyclooctadiene lignans in the elicited microshoot 
cultures of Schisandra chinensis (Chinese magnolia vine). Appl Microbiol Biot 102:945-959. https://doi.org/10.1007/s00253-017-8640-7

Thomford NE, Senthebane DA, Rowe A, Munro D, Seele P, Maroyi A, Dzobo K (2018) Natural products for drug discovery in the 21st century: innovations for novel drug discovery. Int J Mol Sci 19:1578. https://doi.org/10. 3390/ijms19061578

Tiwari V, Darmani NA, Yue BYJT, Shukla D (2010) In vitro antiviral activity of neem (Azardirachta indica L.) bark extract against herpes simplex virus type-1 infection. Phytother Res 24:1132-1140. https://doi.org/10.1002/ ptr.3085

Udomsuk L, Jarukamjorn K, Tanaka H, Putalun W (2011) Improved isoflavonoid production in Pueraria candollei hairy root cultures using elicitation. Biotechnol Lett 33:369-374. https://doi.org/10.1007/s10529-010-0417-3

van der Heijden R, Threlfall DR, Verpoorte R, Whitehead IM (1989) Regulation and enzymology of pentacyclic triterpenoid phytoalexin biosynthesis in cell suspension cultures of Tabernaemontana divaricata. Phytochemistry 28:2981-2988. https://doi.org/10.1016/0031-9422(89)80264-X
Vasconsuelo A, Boland R (2007) Molecular aspects of the early stages of elicitation of secondary metabolites in plants. Plant Sci 172:861-875. https:// doi.org/10.1016/j.plantsci.2007.01.006

Yan Q, Shi M, Ng J, Wu JY (2006) Elicitor-induced rosmarinic acid accumulation and secondary metabolism enzyme activities in Salvia miltiorrhiza hairy roots. Plant Sci 170:853-858. https://doi.org/10.1016/j.plantsci.2005.12. 004

Yoon HJ, Kim HK, Ma C-J, Huh H (2000) Induced accumulation of triterpenoids in Scutellaria baicalensis suspension cultures using a yeast elicitor. Biotechnol Lett 22:1071-1075. https://doi.org/10.1023/A:1005610400511

\section{Publisher's Note}

Springer Nature remains neutral with regard to jurisdictional claims in published maps and institutional affiliations.

\section{Submit your manuscript to a SpringerOpen ${ }^{\circ}$ journal and benefit from:}

- Convenient online submission

- Rigorous peer review

- Open access: articles freely available online

- High visibility within the field

- Retaining the copyright to your article

Submit your next manuscript at $\boldsymbol{\nabla}$ springeropen.com 